Vol.2, No. 1, Jan. 2019

\title{
INFLUENCE OF TAXES, EXCHANGE RATE, PROFITABILITY, AND TUNNELING INCENTIVE ON COMPANY DECISIONS OF TRANSFERRING PRICING
}

\author{
Citra Syifa Azzura*), Aditya Pratama \\ Universitas Pamulang \\ Email : aditya.pratama.999999@gmail.com
}

\begin{abstract}
This study aims to analyze the influence of Taxes, Exchange Rate, Profitability, and Tunneling Incentive on Company Decisions to Make Transfer Pricing in manufacturing companies. The dependent variable in the study is transfer pricing while the independent variables in this study are tax, exchange rate, profitability, and tunneling incentive. The sample was chosen using a purposive sampling method with certain criteria. In accordance with the required data, namely secondary data, this data collection method uses documentation techniques based on the 2013-2017 financial statements. So that a sample of 17 manufacturing companies can be obtained. The results of the analysis of this study indicate that taxes affect the transfer pricing decision. Exchange rates and profitability have no effect on transfer pricing decisions. While the tunneling incentive affects the transfer pricing decision .
\end{abstract}

Keywords : Tax, exchange rate, profitability, tunneling incentive, transfer pricing

\begin{abstract}
Abstrak
Penelitian ini bertujuan untuk menganalisis pengaruh Pajak, Nilai Tukar, Profitabilitas, dan Insentif Tunneling terhadap Keputusan Perusahaan untuk Melakukan Transfer Pricing di perusahaan manufaktur. Variabel dependen dalam penelitian ini adalah transfer pricing sedangkan variabel independen dalam penelitian ini adalah pajak, nilai tukar, profitabilitas, dan insentif tunneling. Sampel dipilih menggunakan metode purposive sampling dengan kriteria tertentu. Sesuai dengan data yang diperlukan, yaitu data sekunder, metode pengumpulan data ini menggunakan teknik dokumentasi berdasarkan laporan keuangan 20132017. Sehingga sampel dari 17 perusahaan manufaktur dapat diperoleh. Hasil analisis penelitian ini menunjukkan bahwa pajak mempengaruhi keputusan penentuan harga transfer. Nilai tukar dan profitabilitas tidak berpengaruh pada keputusan penentuan harga transfer. Sedangkan insentif tunneling mempengaruhi keputusan penentuan harga transfer.
\end{abstract}

Kata kunci: Pajak, nilai tukar, profitabilitas, insentif tunneling, harga transfer 
Vol.2, No. 1, Jan. 2019

\section{PRELIMINARY}

\section{Background}

Globalization of the economy, business, and investment is currently developing very rapidly without knowing national borders. In order to strengthen its global base, multinational companies establish subsidiaries, branches and business representatives in various countries whose purpose is to strengthen strategic alliances and grow market share (market share) of exports and imports of their products in various countries (Sumarsan, 2013) .

The existence of goods and services transactions that occur between taxpayers who have special relationships is the main cause of the emergence of transfer pricing practices.

There is one thing that is of concern to the world of international taxation, which is often that many multinational companies use transfer pricing policies in their corporate tax planning not in accordance with applicable regulations in Indonesia. Thus allowing tax planning with transfer pricing policy becomes an act of tax evasion (tax avoidance). One case of misuse of the use of transfer pricing policies also occurs in Indonesian multinational companies, namely the company PT. Adaro Indonesia revealed in 2009.

PT. Adaro Indonesia (PT. Adaro Energy Tbk) is the second largest coal company in the country that has Enviro Coal's flagship product, low calorie and environmentally friendly coal. The company conducts tax evasion by means of transfer pricing where the company sells coal to its subsidiary, Coaltrade Service International Pte. Ltd in Singapore at prices below its market price. As is known Singapore has a lower tax rate compared to Indonesia. Then, Coaltrade Services International Pte. Ltd. Selling coal to other parties at market prices so that it causes a shift in profits where the taxes paid to Indonesia should be large enough to be small and PT. Adaro gets a big profit because the tax paid in Singapore is small.

In fact, the use of transfer pricing policies carried out by multinational companies has also been regulated by the OECD Guidelines (Organization of Economic Cooperation and Development Gudelines) and Law No. 36 of 2008 in article 18.

Regulations concerning transfer pricing issues relating to taxation are regulated in Law No. 36 of 2008 article 18 concerning Income Tax (Income Tax Law). The article states that the Directorate General of Taxes (DJP) has the authority to re-determine the amount of Taxable Income (PKP) for taxpayers who have special relationships with other taxpayers in accordance with the fairness and prevalence of businesses that are not affected by the arm's length principle. Further rules and details about transfer pricing are also set forth in the Regulation of the Director General of Taxation Number 32 Year 2011. The incentive tunneling is carried out by the controlling shareholder to obtain private benefits. The company conducts this tunneling with the aim of minimizing transaction costs. By tunneling to parties that have special relationships, the costs can be reduced so that it is more economical compared to those who have no special 
relationship. In addition, companies conduct tunneling with the aim of manipulating profits (Marfuah and Azizah, 2014).

Based on research conducted by Hartati, et . al (2015) argue that the tunneling incentive is a behavior of majority shareholders who transfer assets and profits of the company for their own benefit, but minority shareholders bear the costs they charge. Noviastika (2016) argues that companies that have ownership concentrated on one party or one interest tend to do tunneling in it through a transfer pricing transaction. The transfer pricing transaction is carried out through sales between affiliated companies.

Some experts have acknowledged that the activity of transfer prices of multinational companies can trigger misuse that aims to gain higher profits and also efforts to avoid taxes through transactions between multinational companies in a business group. The impact of the transfer price can be in the form of overpricing, or otherwise underpricing. In addition to business motivation, multinational transfer prices are also intended to control, the mechanism of resource flows between group members and the maximization of after-tax profits (Suandy, 2014).

\section{Formulation of the problem}

1. Does tax affect the company's decision to transfer pricing?

2. Does the exchange rate affect the company's decision to transfer pricing ?

3. Does profitability affect the company's decision to transfer pricing ?

4. Does the tunneling incentive affect the company's decision to transfer pricing ?

5. Does tax, exchange rate, profitability and tunneling incentive affect the transfer pricing decision?

\section{Research purposes}

1. To determine the effect of tax on the company's decision to conduct transfer pricing.

2. To determine the effect of e xchange rate on the company's decision to conduct transfer pricing .

3. To determine the effect of profitability on the company's decision to conduct transfer pricing .

4. To find out the effect of tunneling incentive on the company's decision to conduct transfer pricing .

5. To find out the effect of tax, exchange rate, profitability and tunneling incentive on the company's decision to conduct transfer pricing.

\section{LITERATURE REVIEW}

\section{Theoretical basis}

\section{Agency Theory}

Agency theory involves two parties, namely, the agent, which in this case is the manager and the principal, namely the owner of the company. According to Irpan (2010) what is meant by agency theory is a theory that states that there are 
differences in interests between owners (shareholders), directors (professional companies) and company employees. And then it will cause conflict between the interests of individuals and the interests of the company.

According to Colgan (2001), factors that can cause agency problems arise, namely:

1. Moral hazard

This generally occurs in large companies (high complexity), where a manager performs activities that are not entirely known by shareholders and lenders. Managers can take action outside the knowledge of shareholders who violate the contract and actually ethically or norms may not be feasible.

2. Detention profit (earnings retention)

This problem revolves around the tendency to over-invest by management ( agents ) through improvement and growth with the aim of increasing power, prestige or appreciation for themselves, but can destroy the welfare of shareholders.

3. Time horizon

This conflict arises as a result of cash flow conditions, where the principal places more emphasis on cash flows for the future whose conditions are uncertain, while management tends to emphasize matters relating to their work.

4. Managerial risk avoidance

This problem arises when there is a limitation of portfolio diversification related to managerial income for the performance achieved, so managers will try to minimize the risk of company shares from investment decisions that increase the risk. For example, management is more pleased with equity funding and trying to avoid borrowing debt, because of bankruptcy or failure.

Tax

\section{Understanding of Taxes}

According to Article 1 of Law 28 of 2007 concerning General Provisions and Tax Procedures, it states that "Tax is a compulsory contribution to the State owed by an individual or an entity that is compelling based on the law by receiving reciprocity directly and used for State purposes. for the greatest prosperity of the people. "

In addition, the definition of tax stated by experts, one of which is according to Soemitro in Mardiasmo (2008) Tax is people's contributions to the State treasury based on the Law (which can be forced) by not receiving reciprocal services that can be directly shown and that is used to pay for public expenses.

\section{Exchange Rate}

\section{Definition of Exchange Rate}

According to Mulyani (2014) said that the price of a currency relative to other currencies (exchange rate) is very dependent on the strength of supply and demand of the currency. The difference in the real exchange rate with the nominal exchange rate is important to understand because both have different effects on exchange rate risk. Changes in the nominal exchange rate will be followed by changes in the same price which makes these changes do not affect the position of 
relative competition between domestic companies and foreign competitors and there is no effect on cash flow. While changes in the real exchange rate will cause changes in relative prices (i.e. changes in the ratio between prices of domestic goods and prices of foreign goods). Thus these changes affect the competitiveness of domestic goods.

\section{Profitability}

The ultimate goal that the company wants to achieve is the most important thing is to get maximum profit or profit, in addition to other things. By gaining maximum profit as targeted, the company can do much for the welfare of the owners, employees, and improve product quality and make new investments .

Recruiting Kasmir (2012), profitability is a ratio to assess a company's ability to seek profits. This ratio also provides a level of management effectiveness for a company. This is indicated by profits generated from sales and investment income. The point is the use of this ratio shows the efficiency of the company.

\section{Tunneling Incentive}

Hartati, et . al (2015) states that tunneling incentive is a behavior of majority shareholders who transfer company assets and profits for their own benefit, but costs are also borne by minority shareholders. Whereas according to Klassen, et . al (2013) tunneling incentive is the activity of majority shareholders who prioritize their own interests and harm minority shareholders.

According to Brundy, et . al (2014) tunneling can appear in two forms. First, the controlling shareholder can transfer resources from the company to himself through transactions between the company and the owner. These transactions can be done through asset sales, transfer price contracts, excessive executive compensation, lending, and others. Second, controlling shareholders can increase their share of the company without transferring assets through the issuance of dilutive shares or other financial transactions that result in losses for non-controlling shareholders.

Marfuah and Azizah (2014) stated that as an effort to reduce and prevent tunneling activities, companies should implement an effective monitoring mechanism. Through supervision carried out by many parties who are considered independent, it will limit the scope that is often used by controlling shareholders to conduct tunneling.

In this ownership structure, shareholders are generally not willing to carry out monitoring, because they have to bear all monitoring costs and only enjoy profits in proportion to their share ownership. Thus, agency conflicts that occur in scattered ownership structures are agency conflicts between managers and shareholders (Jensen and Meckling, 1976 in Yuniasih et al, 2012).

\section{Transfer Pricing Definition}


According to Horngren (2008: 375), what is meant by transfer pricing is the price charged by a subunit for a product or service supplied to another subunit in the same organization .

The Organization for Economic Co-operation and Development (OECD) defines transfer pricing as a price determined in transactions between group members in a multinational company, where the specified transfer price can deviate from the fair market price as long as it is suitable for the group.

Based on Article 1 paragraph (8) of the Director General of Taxes Regulation Number PER-32 / PJ. / 2011, it defines transfer pricing , namely "Determination of prices in transactions between parties that have special relations". Whereas according to the Statement of Financial Accounting Standards (PSAK) No. 7 (2015 Adjustment), parties that have a special relationship are if one party has the ability to control another party, or has a significant influence on the other party in making a decision. Transactions between parties that have a special relationship are a transfer of resources, or obligations between parties that have a special relationship, regardless of whether a price is calculated.

\section{RESEARCH METHODOLOGY}

\section{Types of research}

This type of research is quantitative research with a quantitative descriptive approach. The approach of this research uses descriptive quantitative which aims to explain empirical phenomena accompanied by statistical data and patterns of relationships between variables which are analyzes of influence.

The data used is secondary data, namely research data sources obtained indirectly through intermediary media. The research data is sourced from the annual financial statements of manufacturing companies listed on the Indonesia Stock Exchange (IDX) in 2013-2017 obtained from www.idx.co.id.

The scope of this study is only limited to an explanation of the tests conducted regarding the effect of tax, exchange rate, profitability and tunneling incentive on the dependent variable, namely the company's decision to conduct transfer pricing.

\section{Research sites}

The location used in this study came from www.idx.co.id. Then the data taken is in the form of annual financial reports from each manufacturing company listed on the Indonesia Stock Exchange (IDX) in the period 2013-2017.

\section{Variables and Measurements}

Tax

\section{Exchange Rate}

An exchange rate is an agreement known as the currency exchange rate for current or future payments between two currencies of each country or region. Fluctuations in currency exchange rates make it possible for multinational companies to try to reduce the risk of foreign exchange rates by transferring funds 
to a strong currency through transfer pricing to maximize overall corporate profits. This is because the exchange rate has two accounting effects, namely to include foreign currency transactions and disclosure of profits and / or losses that can affect the company's overall profits.

\section{Profitability}

There are various measures of profitability, but those that are directly related to the interests of analyzing the company's financial performance are ROA ( Return On Assets). This ratio measures a company's ability to generate profits from the total assets used. The higher the ratio, the more effective the use of an asset in generating profits.

\section{Tunneling Incentive}

Tunneling incentive is proxied by the percentage of share ownership above $20 \%$ which is the controlling shareholder by a foreign company. Concentrated ownership structure criteria based on PSAK No. 15 which measures the significant influence of shareholders by foreign parties by using a percentage of share ownership of $20 \%$ or more can influence or control the operations of the company.

\section{Transfer pricing decisions}

This study uses transfer pricing variables as the dependent variable. The measurement instrument to be used in this study refers to the instrument used by Andika (2017), where transfer pricing symbolized by (Y) is measured using a dummy variable, meaning that the value of the variable is limited to 0 and 1 only.

\section{Population and Samples Population}

The population studied in this study are all manufacturing companies listed on the Indonesia Stock Exchange (IDX) in the period 2013-2017 and have been published. The population in this study amounted to 154 manufacturing companies.

\section{Sample}

Sampling in this study uses purposive sampling technique, which is a sample based on the suitability of the characteristics of the sample with predetermined sample selection criteria. The sample criteria used in this study are:

1. Manufacturing companies listed on the Indonesia Stock Exchange in 20132017.

2. A manufacturing company listed on the IDX that publishes annual financial statements stated in rupiah (Rp.).

3. Manufacturing companies controlled by foreign companies with ownership percentage of $20 \%$ or more.

4. The sample companies did not experience losses during the period observation.

5. The sample company has foreign exchange profit / loss data. 


\section{Feasibility Test Regression Model}

The feasibility of the regression model is assessed using the Hosmer and Lemeshow's Goodness of Fit Test, testing the null hypothesis that empirical data is suitable or in accordance with the model (there is no difference between the model and the data so that the model can be fit ). If the Hosmer and Lemeshow's statistical value of Goodness of Fit Test is equal to or less than 0.05 , then the null hypothesis is rejected.

\section{Logistic Regression Analysis}

This study uses a quantitative data method using statistical analysis through logistic regression analysis. Logistic regression analysis is an analytical tool used to measure how far the influence of independent variables on the dependent variable, in this case the dependent variable in the form of a dummy variable (between 0 and 1 ).

In logistic regression analysis does not require a classic assumption test because in logistic regression analysis a fit model analysis is produced which describes whether the data from this study is good for use in research (Ghozali, 2016).

\section{Test Statistics t (Partial)}

According Ghozali (201 6) statistical test $t$ basically shows how far the influence of the explanatory variables / independent individual (partial) in explaining the dependent variable. Tests are carried out using a significance level of $0.05(\alpha=5 \%)$.

\section{Test F Statistic (Simultaneous)}

According to Ghozali (2016) this test is to see how the influence of independent variables together (simultaneous) on changes in the value of the dependent variable. For this reason, an F test is needed which is done by comparing the significant level set for the study with the probability value of the research results.

\section{RESULTS AND DISCUSSION}

\section{Overview of Research Objects}

The population in this study are manufacturing companies listed on the Indonesia Stock Exchange (IDX) during the period 2013-2017. The data processing of this research uses SPSS electronic version 22, 0 to facilitate data processing so that it can explain the variables studied.

The method used to determine the sample in this study was selected by purposive sampling where this study indicated that the sample used was a representation of the existing population. 


\section{CONCLUSION}

Based on the results of research on manufacturing companies listed on the Indonesia Stock Exchange (IDX) for the period 2013-2017, conclusions can be taken as follows:

1. Tax has a significant effect on the company's decision to transfer pricing to manufacturing companies in the period 2013-2017, so that $\mathrm{H}_{1}$ is accepted.

2. Exchange rate does not significantly influence the company's decision to transfer pricing to period manufacturing companies 2013-2017, so $\mathrm{H}_{2}$ is rejected.

3. Profitability does not significantly influence the company's decision to transfer pricing to manufacturing companies in the period 2013-2017, so that $\mathrm{H}_{3}$ is rejected.

4. Tunneling incentives significantly influence the pricing decisions at manufacturing transfe 2013-2017 period, so that $\mathrm{H}_{4}$ is received.

5. Tax, exchange rate, profitability, and tunneling incentive significantly influence the transfer pricing decision on manufacturing companies in the period 2013-2017, so that $\mathrm{H}_{5}$ is accepted.

\section{Limitations}

This study has several limitations that can be corrected by future researchers to get better results. The limitations in this study are:

1. The sample of this company is only 17 companies.

2. The variables used are only focused on certain companies that fit the research criteria.

3. The time available to complete this study is relatively short so that the results of the study cannot be explored in depth.

\section{Suggestion}

Based on the conclusions above, this study is expected to be able to present the results of a more qualified study, with several inputs regarding several things including:

1. Further research is recommended to extend or extend the period of research and research so that it can produce more accurate research results and conclusions.

2. Further research is recommended to add another factor in the company's decision to conduct transfer pricing .

3. Further research is suggested to examine other sectors or even examine the entire sector as a sample of research objects. 
Vol.2, No. 1, Jan. 2019

\section{BIBLIOGRAPHY}

Andika, Teguh Rizsky. (2017). The Influence of Taxes, Tunneling Incentive, and Company Size on Company Transfer Pricing Decisions. Pamulang University.

Andraeni, Syarah Sefty. (2017). Effect of Exchange Rate, Tunneling Incentive, and Bonus Mechanism on Company Decisions to Transfer Pricing. Syarif Hidayatullah UIN Jakarta, 2017.

Bringham, Eugene F, and Joel F. Houston. (2010). Fundamentals of Financial Management. Jakarta: Salemba Empat.

Brundy, I Gede Siswantaya, and Edwin Pratama. The Effect of Monitoring Mechanisms on Tunneling Activities. National Symposium Accounting 17 Matara University, Lombok , 2014.

Cash. News, article accessed on January 10, 2017, from http://nasional.kontan.co.id/news/solusi-pajak-toyota-motor-menantipaluhakim, March 26, 2013.

Colgan, Patrick. (2001). Agency Theory and Corporate Governance: A Review of the Literature From a UK Perspective. University of Strsthclyde UK , 2001.

Deanti, Laksmita Rachmah. (2017). Influence of Taxes, Intangible Assets, Accountability, Profitability, and Tunneling Incentives on the Transfer Pricing Decisions of Indonesian Multinational Companies. Syarif Hidayatullah State Islamic University Jakarta , 2017.

Ghozali, Imam. (2016). Application Multivariate Analysis with the SPSS Program. Semarang: BP Undip.

Hapsoro, Dito Tri. (2015). Effects of Taxes, Profitability, Company Size, and Tunneling Incentives on Transfer Pricing Decisions. Syarif Hidayatullah UIN Jakarta.

Hartati, W., Desmitawati, and Azlina, N. (2015). Analysis of the Effects of Taxes and Bonus Mechanisms on Transfer Pricing Decisions. National Symposium on Accounting XVII, Mataram.

Horngren, Charles T., Srikant M. Datar, and George Fost. (2008). Cost Accounting: Managerial Emphasis. Jakarta: Erlangga.

Ilyas, Wirawan B., and Rudy, Suhartono.(2009). Comprehensive, Easy and Practical Guide, Income Tax . Jakarta: Institute of Publishers of the Faculty of Economics, University of Indonesia.

Irpan. (2010). Analysis of the Effect of the Board of Directors Bonus Scheme, Business Type, Company Profitability, and Company Size on Earning Management. Syarif Hidayatullah State Islamic University Jakarta , 2010.

Kasmir. (2012). Analysis of Financial Statements. Jakarta: Raja Wali Press , 2012. Kewal, Suramaya Suci. (2012). Effects of Inflation, Interest Rates, Exchange Rates, and GDP Growth on the Composite Stock Price Index. Economia Vol.8 Journal No.1 Musi College of Economics Palembang.

Klassen, Kennet, et al. , " Transfer Pricing: Strategies, Practices, and Tax Minimization ", KPMG , 2013.

Mardiasmo. (2008). Taxation. Revised Edition of Andi Yogyakarta Publisher: Yogyakarta. 
Marfuah, and Andri Puren Noor Azizah. (2014). The Influence of Taxes, Tunneling Incentives and Exchange Rate on Corporate Transfer Pricing Decisions. Journal of Indonesian Accounting and Auditing.

Mario, Arthur. (2010). Analysis of Transfer Pricing Policies for Intercompany Transactions in Efforts to Conduct Tax Efficiency. University of Indonesia Thesis, Tax Administration Science Department, Depok.

Mispiyanti. (2015). Influence of Taxes, Tunneling Incentive, and Bonus Mechanism on Transfer Decisions of Company Decisions. STIE Putra Bangsa.

Mulyani, Neny. (2014). Analysis of the Effects of Inflation, Interest Rates, Rupiah Exchange Rates, and Gross Domestic Product on the Jakarta Islamic Index. Journal of Executive Business and Management Vol.1 No.1 , Open University.

Noviastika, Dwi, Yuniadi Mayowan, and Suhartini Karjo. (2016). The Influence of Taxes, Tunneling Incentive, and Good Corporate Governance (GCG) on Indications of Transfer Pricing to Manufacturing companies listed on the Indonesia Stock Exchange. Journal of Taxation.

Official, Siti. (2013). Taxation Theory and Case. Jakarta: Salemba Empat, 2013.

Richardson, Grant, Grantley Taylor, and Roman Lanis. (2013). Determinants of transfer pricing aggressiveness: Empirical evidence from Australian firms. Journal of Contemporary Accounting \& Economics.

Setiawan, Hadi. the article was accessed on March 17, 2018, from http://www.kemenkeu.go.id/sites/default/files/2014_kajian_pprf_Transfer\%2 0Pricing\%20dan\%20Risikonya\%20Terhadap\%20Penerimaan\%20Negara.pd f, 2014 .

Sikka, Premm and Hugg Willmott. (2010). The Dark Side of Transfer Pricing: Its Role in Tax Avoidance and Wealth. Critical Perspectives on Accounting 21.

Suandy, Erly. ((2014). Tax Law . Jakarta: Salemba Empat, 2014.

Sugiyono. (2016). Quantitative, Qualitative and $R \& D$ Research Methods. Bandung: Alfabeta.

Sumarsan, Thomas. (2013). Tax Review and Tax Planning Strategy. Jakarta: Index, 2013

Wafiroh, Novi L, and Niken Nindya Hapsari. (2015). Influence of Taxes, Tunneing Incentive, and Bonus Mechanisms in Transfer Pricing Decisions. UIN Maulana Malik Ibrahim Malang.

Waluyo. (2011). Indonesian taxation. Jakarta: Salemba Empat, 2011.

Yuniasih, Ni Wayan, Ni Ketut Rasmini, and Made Gede Wirakusuma. (2012). The Influence of Taxes and Tunneling Incentives on Manufacturing Company Transfer Pricing Decisions that are listed on the Indonesia Stock Exchange. National Accounting Symposium 15.

www.idx.co.id (accessed September 7, 2018)

www.ortax.org

www.pajak.go.id 